\title{
Risk factors for macrovascular disease in diabetes mellitus: the London follow-up to the WHO Multinational Study of Vascular Disease in Diabetics
}

\author{
N.J.Morrish' ${ }^{1}$, L.K.Stevens ${ }^{3}$, J.H. Fuller ${ }^{3}$, R.J.Jarrett ${ }^{2}$ and H. Keen ${ }^{1}$ \\ ${ }^{1}$ Unit for Metabolic Medicine and ${ }^{2}$ Department of Community Medicine, United Medical and Dental Schools (Guy's Campus) and \\ ${ }^{3}$ Department of Community Medicine, University College, London
}

\begin{abstract}
Summary. We have examined the relationship between baseline variables and the incidence of new macrovascular complications amongst the 497 members of the London cohort of the WHO Multinational Study of Vascular Disease in Diabetics over a mean 8.33-year follow-up. In univariate logistic regression analysis the incidence of new ischaemic electrocardiographic abnormality was significantly associated with systolic and diastolic blood pressure, diabetes duration and hypertension in patients with insulin-dependent diabetes, and with smoking in patients with non-insulin-dependent diabetes. New myocardial infarction was associated with systolic blood pressure, plasma cholesterol, proteinuria and smoking in patients with non-insulin-dependent diabetes; there were no significant associations among patients with insulin-dependent diabetes. All new ischaemic heart disease was associated with hypertension in patients with insulin-dependent diabetes, and plasma cholesterol and smoking in patients with non-insulin-dependent diabetes. New cerebrovascular disease was associated with systolic and diastolic blood pressure, ECG abnormality and hyperten-
\end{abstract}

sion. New peripheral vascular disease was associated with smoking. Multivariate analysis showed the following significant associations 1) in patients with insulin-dependent diabetes: ECG abnormality; hypertension, myocardial infarction; smoking, ischaemic heart disease; hypertension, diabetes duration and smoking, 2) in patients with non-insulin-dependent diabetes: ECG abnormality; smoking, myocardial infarction; serum cholesterol, proteinuria and smoking, ischaemic heart disease; smoking. For new cerebrovascular disease, proteinuria and ECG abnormality were significant predictors in multivariate analysis. Patients with diabetes share many of the established risk factors for nondiabetic subjects, in addition proteinuria may be of significance in the prediction of macrovascular disease in diabetes.

Key words: Insulin-dependent diabetes mellitus, non-insulin-dependent diabetes mellitus, ischaemic heart disease, myocardial infarction, electrocardiography, cerebrovascular disease, peripheral vascular disease, risk factors.
Risk factors for atherosclerosis in the general population have been widely documented but there are few prospective studies of these in relation to the macrovascular complications of diabetes. We now report on the associations between a number of characteristics systematically ascertained at the baseline examination and incident events of vascular disease over the ensuing mean follow-up period of 8.3 years (range 6.0-10.1) in the 497 members of the London cohort of the WHO Multinational Study of Vascular Disease in Diabetics.

\section{Subjects and methods}

The recruitment and composition of the patient cohort and the ascertainment methods of the WHO Multinational Study have been described elsewhere [1]. The follow-up study including definitions of diabetes type and of the outcome variables used in this report and details of the completeness of follow-up is described by Morrish et al. [2].

Proteinuria was considered as being present if there was any degree of visible precipitation with the salicylsulphonic acid test [3]. The definition of hypertension includes those patients with elevated blood pressure (systolic blood pressure $\geqslant 160$ or diastolic blood pressure $\geqslant 95$ ) and/or those receiving anti-hypertensive medication.

\section{Statistical analysis}

Associations between baseline variables and macrovascular outcome have been sought using logistic regression [4] analysis. The analyses compare the patients with and without evidence of a particular outcome during the follow-up period. Only patients free of the complication at baseline in whom there was adequate follow-up information are included. For continuous variables (eg blood pressure, BMI) a standardised estimate of relative risk (SERR) has been 
Table 1. Mean values $( \pm S D)$ of continuously distributed variables at baseline

\begin{tabular}{|c|c|c|c|c|}
\hline & \multicolumn{2}{|c|}{$\begin{array}{l}\text { Patients with } \\
\text { insulin-dependent } \\
\text { diabetes }(n=243)\end{array}$} & \multicolumn{2}{|c|}{$\begin{array}{l}\text { Patients with } \\
\text { non-insulin-dependent } \\
\text { diabetes }(n=254)\end{array}$} \\
\hline & $\begin{array}{l}\text { Male } \\
n=118\end{array}$ & $\begin{array}{l}\text { Female } \\
n=125\end{array}$ & $\begin{array}{l}\text { Male } \\
n=136\end{array}$ & $\begin{array}{l}\text { Female } \\
n=118\end{array}$ \\
\hline Age (years) & $\begin{array}{l}44.9 \\
(6.0)\end{array}$ & $\begin{array}{l}47.7 \\
(5.6)\end{array}$ & $\begin{array}{l}45.8 \\
(5.6)\end{array}$ & $\begin{array}{l}47.9 \\
(5.3)\end{array}$ \\
\hline $\begin{array}{l}\text { Systolic BP } \\
(\mathrm{mm} \mathrm{Hg})\end{array}$ & $\begin{array}{l}134.8 \\
(20.7)\end{array}$ & $\begin{array}{l}134.0 \\
(22.4)\end{array}$ & $\begin{array}{l}134.2 \\
(21.5)\end{array}$ & $\begin{array}{l}143.2 \\
(26.7)\end{array}$ \\
\hline $\begin{array}{l}\text { Diastolic BP } \\
(\mathrm{mm} \mathrm{Hg})\end{array}$ & $\begin{array}{c}79.0 \\
(10.0)\end{array}$ & $\begin{array}{c}78.9 \\
(12.0)\end{array}$ & $\begin{array}{c}84.2 \\
(11.4)\end{array}$ & $\begin{array}{c}87.8 \\
(12.5)\end{array}$ \\
\hline $\begin{array}{l}\text { Serum cholesterol } \\
(\mathrm{mmol} / \mathrm{)})\end{array}$ & $\begin{array}{l}6.0 \\
(1.0)\end{array}$ & $\begin{array}{c}6.1 \\
(1.2)\end{array}$ & $\begin{array}{c}5.8 \\
(1.2)\end{array}$ & $\begin{array}{l}5.8 \\
(1.2)\end{array}$ \\
\hline $\begin{array}{l}\text { Plasma creatinine } \\
(\mu \mathrm{mol} / \mathrm{l})\end{array}$ & $\begin{array}{c}86.6 \\
(13.3)\end{array}$ & $\begin{array}{c}74.2 \\
(14.1)\end{array}$ & $\begin{array}{c}89.3 \\
(15.9)\end{array}$ & $\begin{array}{c}73.4 \\
(15.0)\end{array}$ \\
\hline $\begin{array}{l}\text { Body mass index } \\
\mathrm{kg} / \mathrm{m}^{2}\end{array}$ & $\begin{array}{l}23.7 \\
(2.5)\end{array}$ & $\begin{array}{l}24.5 \\
(3.5)\end{array}$ & $\begin{array}{l}26.0 \\
(3.7)\end{array}$ & $\begin{array}{l}28.1 \\
(5.1)\end{array}$ \\
\hline $\begin{array}{l}\text { Diabetes duration } \\
\text { (years) }\end{array}$ & $\begin{array}{l}20.2 \\
(9.8)\end{array}$ & $\begin{array}{c}20.0 \\
(11.3)\end{array}$ & $\begin{array}{l}7.0 \\
(5.5)\end{array}$ & $\begin{array}{c}7.9 \\
(6.2)\end{array}$ \\
\hline
\end{tabular}

$\mathrm{BP}=$ blood pressure

Table 2. Baseline values (\%) of categorical variables

\begin{tabular}{|c|c|c|c|c|}
\hline & \multicolumn{2}{|c|}{$\begin{array}{l}\text { Patients with } \\
\text { insulin-dependent } \\
\text { diabetes }(n=243)\end{array}$} & \multicolumn{2}{|c|}{$\begin{array}{l}\text { Patients with } \\
\text { non-insulin-dependent } \\
\text { diabetes }(n=254)\end{array}$} \\
\hline & Male & Female & Male & Female \\
\hline \multicolumn{5}{|l|}{ Smoking: } \\
\hline Current & $47(40 \%)$ & $41(33 \%)$ & $57(42 \%)$ & $42(36 \%)$ \\
\hline Ex-smoker & $39(33 \%)$ & $36(29 \%)$ & $44(32 \%)$ & $19(16 \%)$ \\
\hline Never & $32(27 \%)$ & $48(38 \%)$ & $35(26 \%)$ & $57(48 \%)$ \\
\hline \multicolumn{5}{|l|}{ Proteinuria: } \\
\hline Absent & $95(81 \%)$ & $100(80 \%)$ & $110(82 \%)$ & $93(79 \%)$ \\
\hline Present & $22(19 \%)$ & $25(20 \%)$ & $25(18 \%)$ & $25(21 \%)$ \\
\hline \multicolumn{5}{|l|}{$E C G:$} \\
\hline Normal & $99(84 \%)$ & $105(85 \%)$ & $111(82 \%)$ & $87(75 \%)$ \\
\hline Abnormal & $19(16 \%)$ & $19(15 \%)$ & $24(18 \%)$ & $29(25 \%)$ \\
\hline \multicolumn{5}{|l|}{ Hypertension: } \\
\hline Absent & $94(80 \%)$ & $98(78 \%)$ & $104(77 \%)$ & $73(62 \%)$ \\
\hline Present & $24(20 \%)$ & $27(22 \%)$ & $32(23 \%)$ & $45(38 \%)$ \\
\hline
\end{tabular}

Note: Proteinuria is defined as the presence of any degree of visible precipitation on the salicylsulphonic acid test. Hypertension includes patients with elevated blood pressure (systolic BP $\geqslant 160$ or diastolic $\mathrm{BP} \geqslant 95 \mathrm{~mm} \mathrm{Hg}$ ) and those on anti-hypertensive medication. ECGs were classified as follows; abnormal; major $\mathrm{Q}$ waves or complete left bundle branch block (Minnesota codes 1-1, 1-2, 7-1), ST segment abnormalities if accompanied by abnormal $\mathrm{T}$ waves, minor Q/QS wave changes (Minnesota codes 1-3, or any of 4-1, 4-2, 4-3 if accompanied by 5-1 or 5-2 or 5-3) and normal (all other Minnesota codes)

calculated [exp (estimated beta $\times$ standard deviation)] (where beta is the logistic regression coefficient of the risk factor of interest) and for categorical variables (eg hypertension, proteinuria) an estimate of relative risk (ERR) (exp estimated beta). The SERR gives the relative risk for a change of one unit of standard deviation for a particular variable. $95 \%$ confidence intervals for the estimated relative risks have been calculated ( $\exp$ [standardised beta $\pm 1.96 \times \mathrm{SE}$ estimated beta]). The likelihood ratio test was used to assess whether associations were significant.
Table 3. Univariate logistic regression analysis of association between baseline variables and the development of new ischaemic ECG abnormality during the follow-up by diabetes type (adjusted for age and sex)

\begin{tabular}{|c|c|c|c|c|}
\hline \multirow{2}{*}{ a) Continuous variables } & \multicolumn{2}{|c|}{$\begin{array}{l}\text { Patients with } \\
\text { insulin-dependent } \\
\text { diabetes }\end{array}$} & \multicolumn{2}{|c|}{$\begin{array}{l}\text { Patients with non- } \\
\text { insulin-dependent } \\
\text { diabetes }\end{array}$} \\
\hline & & & & \\
\hline & SERR & $95 \% \mathrm{CI}$ & SERR & $95 \% \mathrm{CI}$ \\
\hline Systolic blood pressure & $1.57^{\mathrm{a}}$ & $1.1-2.4$ & 1.48 & $1.0-2.0$ \\
\hline Diastolic blood pressure & $1.68^{\mathrm{a}}$ & $1.1-2.5$ & 1.07 & $0.7-1.6$ \\
\hline Plasma cholesterol & 1.12 & $0.7-1.7$ & 1.48 & $1.0-2.2$ \\
\hline Plasma creatinine & 1.09 & $0.7-1.8$ & 0.94 & $0.8-1.6$ \\
\hline Body mass index & 1.12 & $0.8-1.7$ & 1.11 & $0.8-1.6$ \\
\hline Diabetes duration & $1.50^{4}$ & $1.01-2.2$ & 1.08 & $0.6-1.9$ \\
\hline \multicolumn{5}{|l|}{ b) Categorical variables } \\
\hline & ERR & $95 \% \mathrm{CI}$ & ERR & $95 \% \mathrm{CI}$ \\
\hline Proteinuria & 0.98 & $0.5-1.8$ & 1.55 & $1.0-2.5$ \\
\hline Hypertension & $1.66^{\mathrm{a}}$ & $1.1-2.6$ & 1.31 & $0.9-2.0$ \\
\hline Smoking & 1.45 & $0.8-2.5$ & $2.04^{\mathrm{a}}$ & $1.2-3.5$ \\
\hline
\end{tabular}

a $p<0.05$

$\mathrm{SERR}=$ standard estimate of relative risk; ERR = estimate of relative risk; $\mathrm{CI}=$ confidence interval

Baseline variables where $p<0.1$ in the univariate analyses were entered into stepwise multivariate logistic regression analyses for association with the outcome variables.

The analysis for smoking includes current smokers, ex-smokers and non-smokers at baseline. The results are expressed as a single relative risk with smoking entered as a single variable with values of non-smokers $=0$, ex-smokers $=1$ and current smokers $=2$. Two indicator variables were also defined a) non-smokers $(0)$ vs current smokers (1) and b) non-smokers (0) vs ex-smokers (1); the results for the 'single' variable in univariate analysis were similar to those for the 'non-smokers vs current smokers' indicator variable; none of the analyses for 'ex-smokers vs non-smokers' were statistically significant and results quoted are those for the single variable including all three groups. The single variable was also used in the multivariate analysis in order to maximise the numbers included.

In the multivariate analysis presented, hypertension was entered as a categorical variable rather than using systolic or diastolic blood pressure as continuous variables. This was chosen because antihypertensive treatment would have modified the recorded arterial blood pressure in a significant number of the patients.

\section{Results}

The analysis for baseline risk factor associations with the heart disease outcome variables, myocardial infarction, ischaemic ECG abnormality and total ischaemic heart disease has been performed separately for patients with insulin-dependent diabetes and with non-insulin-dependent diabetes and adjusted for age and sex. In view of the small numbers of new cases of cerebrovascular and peripheral vascular disease the observations from both diabetes types were pooled and were adjusted for age, sex and diabetes type.

Baseline values of the variables tested for prediction of macrovascular disease outcome are given in Tables 1 and 2. Numbers of cases and incidence rates for the macrovascular outcome variables are published elsewhere [2]. 
Table 4. Univariate logistic regression analysis of association between baseline variables and the development of new myocardial infarction during the follow-up by diabetes type (adjusted for age and sex)

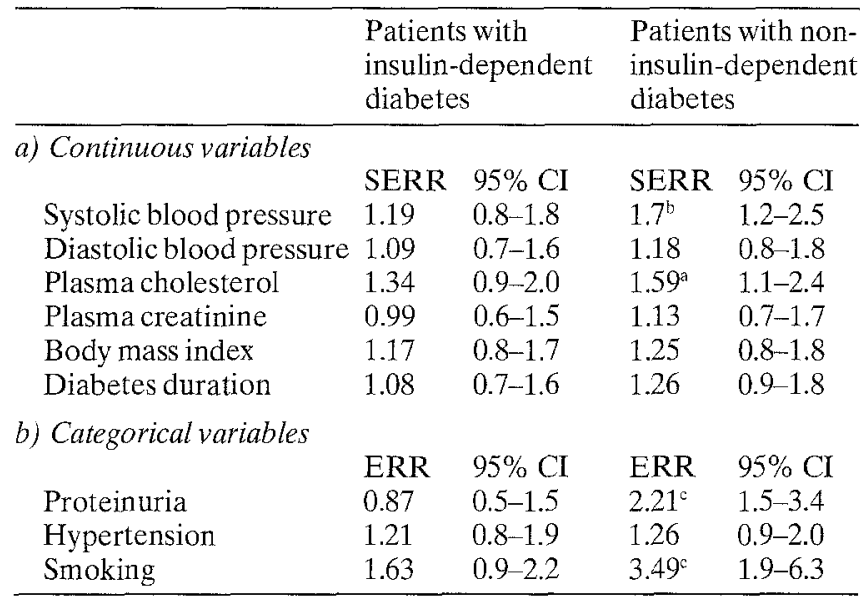

${ }^{\mathrm{a}} p<0.05 ;{ }^{\mathrm{b}} p<0.01 ;{ }^{\mathrm{c}} p<0.001$

$\mathrm{SERR}=$ standard estimate of relative risk; ERR = estimate of relative risk; $\mathrm{CI}=$ confidence interval

The results of univariate logistic regression relating baseline variables to macrovascular outcome are shown in Tables 3-6.

The variables selected by the stepwise multivariate logistic regression analyses as significantly related to the ischaemic heart disease outcome variables are shown in Table 7 and those for cerebrovascular and peripheral vascular disease in Table 8.

\section{Discussion}

Arterial blood pressure is the most consistent baseline predictor of macrovascular events during the follow-up whether taken as continuous variables (systolic/diastolic blood pressure) or as the categorical variable "hypertension' whether in univariate or multivariate analysis. In the study by Krolewski et al. [5] hypertension without proteinuria conferred a relative risk of 6 for coronary artery disease. When proteinuria was also present risk was increased 16 times: all the proteinuric patients were hypertensive. In the Framingham Study [6] hypertension had similar strengths in predicting cardiovascular disease in both diabetic and non-diabetic subjects. From this study it is possible to calculate a SERR of 1.24 for the association between systolic blood pressure and cardiovascular disease in the diabetic members of the study population.

There was no cross-sectional association between smoking and the prevalence of large vessel disease in the WHO Study at baseline [1]. However, cigarette smoking does have associations with incident ischaemic heart disease events. These are significant in all the multivariate analyses in patients with non-insulin-dependent diabetes but not in those with insulin-dependent diabetes although associations of an appreciable magnitude are to be found in the univariate analysis (ERRs 1.4-1.5). Other studies confirm the risks of cigarette smoking in diabetes $[7,8]$.
Smoking is clearly a major extra risk in people with diabetes and should be vigorously discouraged.

In insulin-dependent diabetes clinical proteinuria strongly predicts macrovascular disease [9]. In non-insulin-dependent diabetic patients subclinical elevations of albumin excretion rate (microalbuminuria) carried prognostic significance for cardiovascular death [10] and were cross-sectionally associated with evidence of coronary heart disease [11]. Proteinuria was also associated with ischaemic heart disease in the WHO cohort though less consistently than blood pressure or smoking. In the multivariate analysis it was associated with new myocardial infarction in patients with non-insulin-dependent diabetes. The failure to demonstrate the relationship in patients with insulin-dependent diabetes might be due to the relatively small size of the cohort in this study and thus represent a type 2 error but other factors deserve consideration. The strength of association between ischaemic heart disease and proteinuria in a study will be influenced by the composition of the cohort and the definitions used. Longterm studies in patients with insulin-dependent diabetes from North America [5] and Denmark [12] have shown strong links between manifestations of diabetic kidney disease and cardiovascular disease. Both these reports concern patients followed from diagnosis of diabetes or soon after; in contrast the mean duration of insulin-dependent diabetes at entry to our study was 20.2 years. A relationship between proteinuria and ischaemic heart disease in insulin-dependent diabetes may well have been missed because of the late mean age of entry in this study, explaining its insignificance in our results. The fact that the relationship was demonstrated in patients with noninsulin-dependent diabetes might suggest that proteinuria is a stronger risk factor in patients with this type of diabetes but may simply be a function of the much shorter mean duration of diabetes in the non-insulin-dependent patients. The salicylsulphonic acid method was chosen for the WHO Multinational Study as a simple universally

Table 5. Univariate logistic regression analysis of association between baseline variables and the development of new ischaemic heart disease during the follow-up by diabetes type (adjusted for age and sex)

\begin{tabular}{|c|c|c|c|c|}
\hline \multirow{2}{*}{ a) Continuous variables } & \multicolumn{2}{|c|}{$\begin{array}{l}\text { Patients with } \\
\text { insulin-dependent } \\
\text { diabetes }\end{array}$} & \multicolumn{2}{|c|}{$\begin{array}{l}\text { Patients with non- } \\
\text { insulin-dependent } \\
\text { diabetes }\end{array}$} \\
\hline & & & & \\
\hline & SERR & $95 \% \mathrm{CI}$ & SERR & $95 \% \mathrm{CI}$ \\
\hline Systolic blood pressure & 1.38 & $1.0-2.0$ & $1.48^{a}$ & $1.01-2.2$ \\
\hline Diastolic blood pressure & 1.4 & $1.0-2.0$ & 1.0 & $0.7-1.5$ \\
\hline Plasma cholesterol & 1.22 & $0.9-1.8$ & $1.55^{\mathrm{a}}$ & $1.1-2.2$ \\
\hline Plasma creatinine & 0.86 & $0.6-1.3$ & 0.91 & $0.6-1.4$ \\
\hline Body mass index & 1.06 & $0.8-1.5$ & 0.95 & $0.7-1.4$ \\
\hline Diabetes duration & 1.39 & $1.0-2.0$ & 1.22 & $0.9-1.8$ \\
\hline \multicolumn{5}{|l|}{ b) Categorical variables } \\
\hline & ERR & $95 \% \mathrm{CI}$ & ERR & $95 \% \mathrm{CI}$ \\
\hline Proteinuria & 0.86 & $0.5-1.4$ & 1.42 & $0.9-2.2$ \\
\hline Hypertension & $1.52^{\mathrm{a}}$ & $1.01-2.3$ & 1.13 & $0.8-1.7$ \\
\hline Smoking & 1.39 & $0.9-2.2$ & $2.27^{b}$ & $1.4-3.8$ \\
\hline
\end{tabular}


Table 6. Univariate logistic regression analysis of association between baseline variables and the development of new cerebrovascular disease and new peripheral vascular disease during the follow-up by diabetes type (adjusted for age, sex and diabetes type)

\begin{tabular}{|c|c|c|c|c|}
\hline & \multicolumn{2}{|c|}{$\begin{array}{l}\text { Cerebrovascular } \\
\text { disease }\end{array}$} & \multicolumn{2}{|c|}{$\begin{array}{l}\text { Peripheral vascular } \\
\text { disease }\end{array}$} \\
\hline \multicolumn{5}{|l|}{ a) Continuous variables } \\
\hline & SERR & $95 \% \mathrm{CI}$ & SERR & $95 \% \mathrm{CI}$ \\
\hline Systolic blood pressure & $2.02^{c}$ & 1.4 & 1.14 & $0.8-1.8$ \\
\hline Diastolic blood pressure & $1.74^{\mathrm{a}}$ & $1.1-2.6$ & 1.04 & $0.7-1.6$ \\
\hline Plasma cholesterol & 1.2 & $0.9-1.4$ & 1.29 & $0.9-1.9$ \\
\hline Plasma creatinine & 0.84 & $0.5-1.5$ & 0.86 & $0.3-1.0$ \\
\hline Body mass index & 1.39 & $0.9-2.1$ & 0.91 & $0.6-1.5$ \\
\hline Diabetes duration & 1.37 & $0.8-2.3$ & 1.46 & $0.9-2.4$ \\
\hline \multicolumn{5}{|l|}{ b) Categorical variables } \\
\hline & ERR & $95 \% \mathrm{CI}$ & ERR & $95 \% \mathrm{CI}$ \\
\hline Proteinuria & 1.42 & $0.9-2.3$ & 0.96 & $0.6-1.7$ \\
\hline ECG abnormality & $1.78^{\mathrm{a}}$ & $1.1-2.8$ & 1.21 & $0.7-2.0$ \\
\hline Hypertension & $1.96^{\circ}$ & $1.2-3.1$ & 0.71 & $0.4-1.3$ \\
\hline Smoking & 1.03 & $0.6-1.8$ & $1.79^{\mathrm{a}}$ & $1.01-3.2$ \\
\hline
\end{tabular}

a $p<0.05 ;{ }^{b} p<0.01 ;{ }^{c} p<0.001$

SERR = standard estimate of relative risk; ERR = estimate of relative risk; $\mathrm{CI}=$ confidence interval

Table 7. Significant variables selected by stepwise multiple logistic regression analysis for association between baseline variables and ischaemic heart disease outcome variables (adjusted for age and sex)

\begin{tabular}{|c|c|}
\hline \multicolumn{2}{|c|}{$\begin{array}{l}\text { ECG abnormality } \\
\text { a) Patients with insulin }\end{array}$} \\
\hline & SERR/ERR $(95 \% \mathrm{CI})$ \\
\hline Hypertension & $2.1^{\mathrm{a}}(1.2-3.6)$ \\
\hline \multicolumn{2}{|c|}{ b) Patients with non-insulin-dependent diabetes } \\
\hline \multicolumn{2}{|c|}{$\begin{array}{l}\text { Myocardial infarction } \\
\text { a) Patients with insulin-dependent diabetes }\end{array}$} \\
\hline Smoking & $\begin{array}{l}\text { SERR/ERR (95\% CI) } \\
2.1^{2}(1.1-3.9)\end{array}$ \\
\hline $\begin{array}{l}\text { b) Patients with no } \\
\text { Serum cholesterol } \\
\text { Proteinuria } \\
\text { Smoking }\end{array}$ & $\begin{array}{l}\text { 1-dependent diabetes } \\
1.6^{\mathrm{a}}(1.1-2.6) \\
2.7^{\mathrm{c}}(1.6-4.5) \\
3.6^{\mathrm{c}}(1.8-7.0)\end{array}$ \\
\hline $\begin{array}{l}\text { Ischaemic heart disea } \\
\text { a) Patients with ins }\end{array}$ & $\begin{array}{l}\text { endent diabetes } \\
\text { SERR/ERR }(95 \% \mathrm{CI})\end{array}$ \\
\hline $\begin{array}{l}\text { Hypertension } \\
\text { Diabetes duration } \\
\text { Smoking }\end{array}$ & $\begin{array}{l}2.4^{\mathrm{b}}(1.6-4.1) \\
1.8^{\mathrm{b}}(1.2-2.7) \\
2.5^{\hat{a}}(1.4-4.6)\end{array}$ \\
\hline $\begin{array}{l}\text { b) Patients with not } \\
\text { Smoking }\end{array}$ & $\begin{array}{l}\text {-dependent diabetes } \\
1.9^{\mathrm{a}}(1.1-3.4)\end{array}$ \\
\hline
\end{tabular}

${ }^{\mathrm{a}} p<0.05 ;{ }^{\mathrm{b}} p<0.01 ;{ }^{\circ} p<0.001$

SERR = standard estimate of relative risk; ERR = estimate of relative risk; $\mathrm{CI}=$ confidence interval

available test for proteinuria. It has been reported to correlate well with other tests such as albustix [3]. In the study of Rennie et al. [3] the salicylsulphonic acid test slightly under-reported proteinuria when compared to other methods, but this would affect both diabetes types similarly. Tolbutamide may cause false positive results with the salicylsulphonic acid test but as very few patients were being treated with this sulphonylurea it is very unlikely to have affected results significantly. Our results
Table 8. Significant variables selected by stepwise multiple logistic regression analysis for association between baseline variables and incidence of new cerebrovascular and peripheral vascular disease (adjusted for age, sex and diabetes type)

\begin{tabular}{lll}
\hline & ERR & $95 \% \mathrm{CI}$ \\
\hline a) Cerebrovascular disease & & \\
Proteinuria & $1.67^{\mathrm{a}}$ & $1.01-2.8$ \\
Ischaemic ECG abnormality & $1.74^{\mathrm{a}}$ & $1.04-2.9$
\end{tabular}

b) Peripheral vascular disease: Nil.

${ }^{a} p<0.05$

$\mathrm{ERR}=$ estimate of relative risk $; \mathrm{CI}=$ confidence interval

give further support to the finding that proteinuria can predict ischaemic heart disease in diabetes mellitus. The mechanism and significance of this recently recognised factor remains to be further explored.

Total serum cholesterol at baseline was significantly predictive in the multivariate analysis for new myocardial infarction in patients with non-insulin-dependent diabetes. Total serum cholesterol was not a significant risk factor for the incidence of coronary heart disease in patients over 50 years in the Framingham study [13] and most current interest centres on risks associated with the specific lipoprotein fractions.

Diabetes duration is accepted as a prominent determinant of the microvascular complications of diabetes but its relationship with arterial disease is contested [14]. In the present study known diabetes duration was significantly related to ischaemic heart disease in the multivariate analysis in patients with insulin-dependent diabetes. Jarrett [14] has argued that the enhancement of atherosclerosis in non-insulin-dependent diabetes is a parallel process independent of the diabetes itself. The association of diabetes duration with incidence of ischaemic heart disease in this study in patients with insulin-dependent diabetes but not in those with non-insulin-dependent diabetes is consistent with this theory. However, the patients with non-insulindependent diabetes in the London Cohort had disease of relatively short duration. Data from other centres in the WHO study (unpublished) suggest that duration may be related to some aspects of macrovascular disease in noninsulin-dependent diabetes. Krolewski et al. in their study of patients with insulin-dependent diabetes [5] found that cumulative mortality from coronary heart disease was a function of attained age but was not related to age at onset of diabetes; they did not analyse specifically by diabetes duration. Their results are therefore at odds with ours which suggest that duration, after correcting for age, is predictive of ischaemic heart disease in patients with insulin-dependent diabetes. The reason for this difference may again possibly be due to the very different nature of the two cohorts. The SERRs for the associations between diabetes duration and cerebrovascular disease and peripheral vascular disease are both positive although nonsignificant.

In view of the small number of cases of new cerebrovascular disease the strength of some of the risk factor associations is of particular interest. Hypertension had the highest attributable risk of the factors studied for atherothrombotic brain infarction in the Framingham Study 
[15], with smoking making a small positive contribution in men and a negative one in women. Smoking carries no significant excess risk of cerebrovascular disease in this study. The strength of the associations of blood pressure and cerebrovascular disease suggests that the effect of adequate blood pressure control in diabetes might be of particular benefit. The independent association with proteinuria seen in multivariate analysis is a further indication of the close links between the renal manifestations of diabetes and large vessel disease and suggests that this effect may be mediated by mechanisms other than arterial blood pressure.

The only baseline variable significantly associated with peripheral vascular disease in the univariate analysis was smoking. In the study of Kreines et al. [16] of the variables examined only serum triglyceride was associated with peripheral vascular disease in men only. In a study of peripheral arterial disease in newly diagnosed patients with noninsulin-dependent diabetes Siitonen et al. [17] found that associations with cardiovascular risk factors were absent or low. The association noted with smoking in this study is supported by the results from Framingham where smoking contributed the highest population attributable fraction for intermittent claudication among men with diabetes but not women [15]. This association is again of particular interest due to the possibility of its modification. by intervention.

These prospective results confirm that the established cardiovascular risk factors in the general population are also important in the diabetic individual. The recently recognised links with proteinuria may be a clue to the mechanisms of the excess cardiovascular disease associated with diabetes. The relationship of diabetes duration to the excess cardiovascular disease seen in diabetes remains unclear although there are some indications that duration (independent of age) may be a risk factor especially in insulin-dependent diabetes.

Acknowledgements. The project was supported by a Medical Research Council Project Grant. We would like to thank the staff of the Diabetic Departments of King's College Hospital and St Thomas' Hospital for their co-operation.

\section{References}

1. The World Health Organisation Multinational Study of Vascular Disease in Diabetics (1985) Prevalence of small vessel and large vessel disease in diabetic patients from 14 centres. Diabetologia 28 [Suppl]: $615-640$

2. Morrish NJ, Stevens LK, Fuller JH, Jarrett RJ, Keen H (1991) Incidence of macrovascular disease in diabetes: the London cohort of the WHO Multinational Study of Vascular Disease in Diabetics. Diabetologia 34: 584-589

3. Rennie IDB, Keen H, Cowhig J, Field M, Harvey M, Quartey E (1967) Evaluation of clinical methods for detecting proteinuria. Lancet II: 489-492

4. Engleman L (1985) BMDP PLR. In: Dixon WJ (ed) BMDP statistical software. University of California Press, Berkely, pp 330 344

5. Krolewski AS, Kosinski EJ, Warram JH et al. (1987) Magnitude and determinants of coronary artery disease in juvenile onset, insulin-dependent diabetes mellitus. Am J Cardiol 59: 750-755

6. Kannel WB, McGee DL (1979b) Diabetes and cardiovascular risk factors: The Framingham study. Circulation 59: 8-13

7. Willett WC, Green A, Stampfer MJ et al. (1987) Relative and absolute risks of coronary heart disease among women who smoke cigarettes. N Engl J Med 317: 1303-1309

8. Rosengren A, Welin L, Tsipogianni A, Wilhelmsen L (1989) Impact of cardiovascular risk factors on coronary heart disease and mortality among middle aged diabetic men: a general population study. Br Med J 299: 1127-1131

9. Jensen T, Borch-Johnsen K, Kofoed-Enevoldson A, Deckert T (1987) Coronary heart disease in young Type 1 (insulin-dependent) diabetic patients with and without diabetic nephropathy: incidence and risk factors. Diabetologia 30: 144-148

10. Mattock M, Morrish NJ, Jackson PG et al. (1990) Microalbuminuria as a predictor of mortality in Type 2 (non-insulin-dependent) diabetic patients: results from a 3-year prospective study. Diabetologia 30 [Suppl]: A49 (Abstract)

11. Mattock MB, Keen H, El-Gohari MR et al. (1988) Coronary heart disease and urinary albumin excretion in Type 2 (non-insulin-dependent) diabetic patients. Diabetologia 31: 82-87

12. Borch-Johnsen K, Kreiner S (1987) Proteinuria: value as a predictor of cardiovascular mortality in diabetes mellitus. Br Med J 294: $1651-1654$

13. Gordon T, Castelli WP, Hjortland MC, Kannel WB, Dawber TR (1977 a) Diabetes, blood lipids and the role of obesity in coronary heart disease risk for women. Ann Int Med 87: 393-397

14. Jarrett RJ (1984) Type 2 (non-insulin-dependent) diabetes mellitus and coronary heart disease - chicken, egg or neither? Diabetologia 26: 99-102

15. Kannel WB, McGee DL (1979a) Diabetes and cardiovascular disease: the Framingham study. JAMA 241: 2035-2038

16. Kreines K, Johnson E, Albrink M et al. (1985) The course of peripheral vascular disease in non-insulin-dependent diabetes. Diab Care 8: 235-243

17. Siitonen O, Uusitupa M, Pyorala K, Voutilanen E, Lansimies E (1986) Peripheral arterial disease and its relationship to cardiovascular risk factors and coronary heart disease in newly diagnosed non-insulin-dependent diabetics. Acta Med Scand 220: 205-212

Received: 7 January 1991

and in revised form: 17 April 1991

Dr. N.J. Morrish

Unit for Metabolic Medicine

Guy's Hospital

London SE1 9RT

UK 